\title{
An Analytical Review on Mandura Bhasma in Classics
}

\author{
Uthamsha. V. $\mathbf{P}^{1}$, T. V.Sreeni ${ }^{2}$ \\ ${ }^{1}$ PG Scholar from Govt Ayurveda College Trivandrum. \\ ${ }^{2}$ Associate Professor, Govt Ayurveda College Trivandrum. \\ Corresponding Author: Uthamsha. V. P
}

\begin{abstract}
Mandura (Iron oxide) is one such drug which has been used since olden days. The reference about mandura bhasma can be seen in many of the rasa texts. It is evident from the Ayurvedic classics that the therapeutic use of mandura has been in practice since the medieval period of Rasasastra. AMndura has a unique place in the treatment of yakrith vikaras.
\end{abstract}

Key words- mandura, sodhana, marana

\section{INTRODUCTION}

Rasa Shastra can be described as Ayurvedic Pharmaceutics, which deals with the drugs of mineral origin, their varieties, characteristics, processing techniques, properties and their therapeutic uses. It is clear from the literature that the metals and minerals were used in treatment in various combinations.

After the development of Rasa Shastra metals like Swarna (Gold), Rajata (Silver), Tamra (Copper), Loha (Iron) etc were found therapeutically useful after processing them by various pharmaceutical processes such as Sodhana, Marana, Amritikarana etc. Rasaushadies gained importance because of their smaller doses and quick relief as compared to herbal drugs in various ailments.

Powder of a substance obtained by calcinations is called bhasma. It is applied to the metals and minerals which are, by special processes, calcined in closed crucibles in pits and with cow dung cakes (Puta). ${ }^{1}$

\section{About the mineral drug mandura Derivation:}

(Mandate Lauham Vestate) - means which covers the Lauha. ${ }^{2}$

\section{Vernacular names of Mandura}

Mandura is the popular name used and other vernacular names are tabulated below.

Table 2.1 Different names of Mandura in other languages

\begin{tabular}{|l|l|l|}
\hline Sl.no & Languages & Names \\
\hline 1. & English & Rusted iron, Slag \\
\hline 2. & Hindi & Mandura, Lohakitta, Singhanaka \\
\hline 3. & Malayalam & Irumbinkittam \\
\hline 4. & Tamil & Manturam, Irumbukittam \\
\hline 5. & Kannada & Lohakitta \\
\hline 6. & Telugu & Lohakittam \\
\hline 7. & Marathi & Mandura \\
\hline 8. & Gujarati & Mandura \\
\hline
\end{tabular}

Table 2.2 Synonyms of Mandura and their possible meaning ${ }^{4}$

\begin{tabular}{|l|l|l|}
\hline sl.no & Synonyms & Meaning \\
\hline 1. & Ayaslishtam & Waste of ayas \\
\hline 2. & Kittam & Waste \\
\hline 3. & Lohabhavam & Created from loha \\
\hline 4. & Lohakittam & Residue of loha \\
\hline 5. & Lohamalam & Waste of loha \\
\hline 6. & Lohaniryasam & Exudates from loha \\
\hline 7. & Lohochishtam & Waste produced from loha \\
\hline 8. & Lohotha & Originated from loha \\
\hline 9. & Malodbhavam & Formed from waste \\
\hline
\end{tabular}

\section{Origin of Mandura:}

After severe heating of Lauha, when it is hammared some parts are separated. 
These separated parts after so many years turn into mandura. ${ }^{5}$ Chemically mandura is iron oxide which is formed when the red hot iron is beaten, it sheds pieces which over a period of time, become a hardened mass in the earth. ${ }^{6}$

\section{Mandura in vedic literature}

Even though other metals and minerals are mentioned in different contexts, reference about mandura or its synonyms were not available in Vedas.

\section{Mandura in samhitas}

Among the classical texts,the word 'lauhakittamandura' and its use in therapeutics was first mentioned in Caraka samhitha. ${ }^{7}$ Sodhana of mandura was also first mentioned by Caraka Samhitha. Importance of sodana of mandura was first mentioned in Rasendra Chudamani $\left(12^{\text {th }}\right.$ century A.D $)^{8}$. Preparation of mandura bhasma was first mentioned by Rasatarangini. in $20^{\text {th }}$ century A.D. ${ }^{9}$

Mandura kalpas are alternative iron formulations mentoned in samhitas. Literary search of different Ayurvedic classics like Bhaishajya Ratnavali, Charakasamhita, Ashtangahridaya, Chakradatta etc reveals many formulations containing mandura as the main ingredient. Majority of formulations are mentioned in the contexts of pandu, kamala, etc which reveals its haematinic effect. Most of the formulations are prepared by Rasakriya or khalviya method and by using gomutra as the processing medium.

\section{Review of Mandurakalpa}

Ayurveda is gifted with vast array of therapeutic formulations, which vary in their pharmacological preparation and drug combinations, due to which they possess multisite action and disease indications. These drugs have wide range of dosage forms which are adopted considering different factors related to the patient and the disease. Mandurakalpas are the promising iron containing herbo-mineral formulations of Ayurveda. Researches had been done on Satavarimandura, Trayushanadimandura, Koladimandura, Kshiramandura, Vajravatakamandura, Punarnavadimandura.

\section{Types of Mandura}

There are two types of classification for describing varieties of mandura.which are based on type of loha from which mandura is originated and time of mandura collected from the earth.

\section{According to type of loha from which Mandura is produced. ${ }^{10}$}

Table 2.3 Types of Mandura according to origin

\begin{tabular}{|l|l|l|}
\hline Tl.no & Name of Mandura & Source(Name of loha) \\
\hline 1. & Mundakitta & Mundaloha \\
\hline 2. & Tikshnakitta & Tikshnaloha \\
\hline 3. & Kantakitta & Kantaloha \\
\hline
\end{tabular}

\section{According to the Age. ${ }^{11}$}

Table 2.4 Classification of mandura according to Age

\begin{tabular}{|l|l|l|}
\hline Sl.no & Name of mandura & No.years \\
\hline 1. & Sarvasreshta mandura & 100 years old \\
\hline 2. & Madhyama mandura & 70 years old \\
\hline 3. & Adhama mandura & 60 years old \\
\hline
\end{tabular}

Another reference of Bhaishajya Ratnavali opines that 80 years old mandura is madhyama. And those mandura which is below 60 years old is considered to be harmful as poison. ${ }^{12}$

\section{Acceptable variety of Mandura}

Many properties have been described for the grahya mandura by different classical texts.

Table 2.5.Physical properties of Mandura according to various texts.

\begin{tabular}{|l|l|l|}
\hline Sl.no & Text books & Physical properties \\
\hline 1. & $\begin{array}{l}\text { Ayurveda } \\
\text { Prakasa }^{10}\end{array}$ & Guru, Snigdham, Nikotaram \\
\hline 2. & $\begin{array}{l}\text { Brihat Rasa } \\
\text { Rajasundaram }^{13}\end{array}$ & $\begin{array}{l}\text { Guru,Snigdham,Akotaram, } \\
\text { Dridam }\end{array}$ \\
\hline 3. & $\begin{array}{l}\text { Rasendra } \\
\text { sarasangraham }^{14}\end{array}$ & Akotaram,Guru,Snigdham,Dridam \\
\hline 4. & Rasa tarangini $^{10}$ & $\begin{array}{l}\text { Snigdham,Guru,Dridam,Krishnam, } \\
\text { Kotaravarjitam, Nashtapurastham }\end{array}$ \\
\hline
\end{tabular}

The mandura which is smooth, heavy, hard, black, solid mass, without fissures which is very old and collected from the place where there are signs of ancient civilizations. 
Table 2.6 Properties of Mandura according to variety of iron origin $^{17}$

\begin{tabular}{|c|c|c|}
\hline Sl.no & $\begin{array}{ll}\text { Name } & \text { of } \\
\text { mandura } & \end{array}$ & Properties \\
\hline 1. & $\begin{array}{l}\text { Mundaloha } \\
\text { kitta }\end{array}$ & Slightly red, heavy and smooth \\
\hline 2. & $\begin{array}{l}\text { Tikshnaloha } \\
\text { kitta }\end{array}$ & $\begin{array}{l}\text { Possess blackish colour like anjana, } \\
\text { heavy, withoutcracks, holes and } \\
\text { fissures. }\end{array}$ \\
\hline 3. & $\begin{array}{l}\text { Kantaloha } \\
\text { kitta }\end{array}$ & $\begin{array}{l}\text { Yellowish, rough, more heavy, without } \\
\text { fissures and cross section surface } \\
\text { exhibits silver like shine. }\end{array}$ \\
\hline
\end{tabular}

\section{Properties of Mandura}

According to the Ayurvedic pharmacology. ${ }^{16}$

$\begin{array}{lll}\text { Rasa } & - & \text { Kashaya } \\ \text { Virya } & - & \text { Sheeta } \\ \text { Vipaka } & - & \text { Katu } \\ \text { Guna } & - & \text { Ruksha,laghu } \\ \text { Doshaghnata } & - & \text { Pittakapha prasamana } \\ \text { Karma - } & \text { Vrisyam, sisiram, }\end{array}$
ruchiramparam, deepanam, pittasamanam, rakthavridhikaram param. ${ }^{11}$

Rasaratnasamuchaya

and

Rasendrasarasangraha opines that all therapeutical qualities present in munda loha exist in mandura also. ${ }^{18,19}$

Indications - Pandu, sopha, kamala, krmi, arsas, grahini, and pliharoga with specific anupana.
Dosage $\quad-114$ ratti to 2 ratti $^{11}$

Therapeutic use of Mandurabhasma in Rasatarangini ${ }^{19}$

Mandura bhasma with punarnavashtaka quata can be used in sotha with ruja.

Mandura bhasma with katvi, triphala and nishadvaya churna can be used in kamala.

With vidanga, triphala, panchakola and abda in krimi, sopha, arsas, grahani, pandu and pliharoga.

Mandura bhasma with desired ratio of Rasasindhura administered daily for one month will act as rakthavridhikaramparam.

With Dasamula kashaya, mandura bhasma can be administered in pandu, atisaram, jwaram, sopham.

\section{Shodhana of Mandura}

Mostly nirvapa (heating up to red hot and quenching in liquid media) process is followed for Sodhana of Mandura. Commonly Gomutra is used as a liquid medium for mandura sodhana. Interestingly, mandura can be used after sodhana making it in churna form. ${ }^{20}$

Table.2.7 Shodhana of mandura mentioned in various texts

\begin{tabular}{|c|c|c|c|c|}
\hline No.of process & Media & Procedure & Repetition & Reference \\
\hline 1 & Gomutra triphala kwatha & Nirvapa & & Rasaratna samuchaya $^{25}$ \\
\hline 2 & Gomutra triphala kwatha & $\begin{array}{l}\text { Abhisheka } \\
\text { Pachana }\end{array}$ & 7 & Sarangadhara samhita ${ }^{26}$ \\
\hline 3 & Gomutra & Pachana & & Caraka samhita $^{27}$ \\
\hline 4 & Gomutra & Nirvapa & $\begin{array}{l}8 \\
7 \\
8 \\
8 \\
7\end{array}$ & $\begin{array}{l}\text { Cakradutta }^{28} \\
\text { Rasaratna samuchaya }^{29} \\
\text { Rasendra sara sangraha }^{30} \\
\text { Ayurveda Prakasa } \\
\text { Rasatarangini }^{32}\end{array}$ \\
\hline 5 & $\begin{array}{l}\text { Taila } \\
\text { Takra } \\
\text { Gomutra } \\
\text { Kanjika } \\
\text { Kulatha }\end{array}$ & Nirvapa & 7 times in each & Rasendrasarasangraha ${ }^{33}$ \\
\hline
\end{tabular}

\section{Marana of Mandura}

Different thought about marana are mentioned in classical text books. Some Rasasastra scholars like Sharangadharacharya, Madhavacharya and the author of Ayurveda Prakasha recommends sodhita mandura itself can be used for therapeutic purposes. They opines that after sodhana, mandura become fine powder, if features of bhasma are not attatined then it should process similarly till it becomes finely powdered. ${ }^{28}$

For marana of mandura following techniques are used in general. Same methods and drugs for processing of loha may be used for marana of mandura. Drugs of lauha maraca gana are used for mandura marana. Thriphala qwatha is the most commonly used liquid media for bhavana. 
Gajaputa is used mostly as heating grade for mandura.

Apart from these methods, Bhaishajyaratnavali (Galagandadhyaya) explains a particular method for preparing mandura bhasma., in which the sodhita mandura should be subjected to soaking in mahishi mootra subjected to puta till it becomes bhasma for one month after that it should be subjected to puta till it becomes bhasma. $^{29}$

The number of putas mentioned by scholars of Rasasastra are tabulated below.

Table 2.8 Marana of Mandura mentioned in different texts

\begin{tabular}{|c|c|c|c|}
\hline Sl.no & Name of text book & $\begin{array}{l}\text { Bhavana } \\
\text { dravya }\end{array}$ & $\begin{array}{l}\text { No. of } \\
\text { putas }\end{array}$ \\
\hline 1. & Rasatarangini $^{11}$ & Triphala quatha & 30 puta \\
\hline 2. & Rasamritam $^{30}$ & $\begin{array}{l}\text { Kumari } \\
\text { swarasa }\end{array}$ & 7 puta \\
\hline 3. & Rasaratnasamuchaya $^{20}$ & \multicolumn{2}{|l|}{ Not mentioning } \\
\hline 4. & $\begin{array}{l}\text { Sharangadhara } \\
\text { samhita }^{31}\end{array}$ & \multicolumn{2}{|l|}{ Not mentioning } \\
\hline 5. & Ayurveda Prakasa $^{25}$ & \multicolumn{2}{|l|}{ Not mentioning } \\
\hline 6. & Rasendra Chintamani $^{32}$ & \multicolumn{2}{|l|}{ Not mentioning } \\
\hline
\end{tabular}

Modern chemistry of Mandura Definition: Mandura is a metallic oxidecum-silicate of iron, generally having the composition $\mathrm{FeSiO}_{4}$.

Broad classification: Metallic oxide cum silicate

\section{Origin and occurrence:}

Mandura is the by product of the metallurgical process during extraction of Iron (Fe) and copper (cu) from their respective ores. It occurs as lumps, boulders of aggregates at the areas where smelting activity is carried out for extraction of copper and iron. Iron is the main constituent of mandura followed by silica with minor amounts of $\mathrm{Cu}, \mathrm{S}, \mathrm{Pb}, \mathrm{Zn}, \mathrm{Ag}, \mathrm{Cd}, \mathrm{Au}$. Mandura is known since ancient times in India and occurs over 500 years old slag dumps near village Singhana (Khetri), dist. Jhunjhunu (Rajasthan). Mandura of similar quality may occur at other places also in the country where smelting of copper was carried out in past.

\section{Physical properties}

Nature : $\quad$ Rough lumpy masses, exhibiting voids

$\begin{array}{lcl}\text { Colour } & : & \text { Black } \\ \text { Streake } & : & \text { Black } \\ \text { Cleavage } & : & \text { None } \\ \text { Fracture } & : & \text { Conchoidal } \\ \text { Lustre } & : & \text { Dull } \\ \text { Tenacity } & : & \text { Brittle but hard } \\ \text { Transparency } & : & \text { Opaque } \\ \text { Magnetism } & : & \text { Non-magnetic } \\ \text { Hardness } & : & 6 \text { to } 6.5 \\ \text { Specific gravity: } & 3 \text { to } 3.8\end{array}$

\section{Chemical assay of Mandura}

1.Mandura should contain not less than $30 \%$ iron $(\mathrm{Fe})$ when analysed by gravimetric method.

2.Mandura should contain not less than $30 \%$ silica when analysed by gravimetric method. 3. Mandura should show not less than $80 \%$ fayalite $\left(\mathrm{FesiO}_{4}\right)$ when studied through XRD method.

4.Heavy metals and arsenic:

Mandoora should not contain more than the statedlimits of the following

Arsenic -6 ppm and Cadmium - 8 ppm.

Other elements may contain the following with $\pm 20 \%$ of the stated limits.

Copper $-0.45 \%$. Zinc - 50 ppm and Silver 7 ppm. $^{42}$

\section{CONCLUSION}

Classical references states that Mandura can be used for therapeutic purpose even after proper sodhana process. Analytical studies on mandura reveals that,it is acombination of silicates, iron compounds, etc. The concept of sodhana for Mandura may be aimed at reducing the silicate content and making it more iron oxide concentrated.Chemical assay on mandura reveals its presence of silica and iron content.Physical properties of mandura include magnetic nature and bhasma form it didn't posses magnetism. Classical reference shows the effect of mandura in various liver disorders which should be explored with proper research methods. Rasaratnasamuchaya and Rasendrasarasangraha opines that all therapeutical qualities present in munda loha exist in mandura also which reveals the relevance of 
munda loha in case of indications of mandura.

\section{Acknowledgement: None}

\section{Conflict of Interest: None}

\section{Source of Funding: None}

\section{REFERENCES}

1. Ayuveda pharmacopeia of India, part1, vol.7, $1^{\text {st }}$ edn.the controller of publications, 2001,Page No.25

2. RajaRadhakanta Deva, Sabdakalpadrumam, Chaukambha Sanskrit series, Varanasi, 2014, part 3, page.no.623

3. Ayurvedic Pharmacopoeia of India, Part I, Vol. 7, 1st edition, The controller of publications, 2001.p31

4. S. K. Kamat Dhanwanthari Nighantu by Dhanwantari, 1st edition. Chowkambha Sanskrit Pratishta (2002).p32 ,33.

5. Sharma. S,Rasatarangini, Hindi Commentary, ShastriKashinath, Motilal Banarasi das, Delhi.517 (2000).

6. Ayurvedic Pharmacopoeia of India, Part I, Vol. 7, 1st edition, The controller of publications, 2001.p.25

7. Sharma R.K. and Daksh B, Agnivesa, Charakasamhita, English translation. Chowkamba Sanskrit Series office varansasi, vol. IV 101 (2000), Sloka20/123 126.

8. Soma dev, Rasendrachudamani, Mishra SN, commentary,

Chaukhambha Orientatia, Varanasi, 262 (2004)

9. Sharma.S,Rasatarangini, Hindi Commentary, ShastriKashinath, Motilal Banarasi das, Delhi. 517 (2000).

10. MishraGularaja Sharma, Ayurveda Prakasha by UpodhyayaMadhava, Carith.Arthvidhyothi Arthaprakashiniskrit and Hindi Commentary), 1st ed Varanasi, Chaukambaorientalia; 2008 sloka 3/287-289

11. Sharma. SRasatarangini, Hindi Commentary, ShastriKashinath, Motilal Banarasi das, Delhi.517 (2000).

12. LochanKanjiv,BhaishajyaRatnavali of GovindaDasji Bhishagratna, Reprint. Vol.1. Varanasi.Chaukambha Sanskrit sansthan, 2008.2 .49
13. DatturamChoumbe, Brhat Rasa Raja Sundhara (with hindi commentary) $3^{\text {rd }}$ ed., Varanasi Chowkambaorientalia2000 Manduraprakaranam. 65sz.

14. Gopalkrishna SatPrakashika, Rasendrasanasamgraham, (with Saty Prakashika commmentary) 1ed., Varanasi ChowkambhaKrishnadasAcademy, 1994. $(1 / 355)$

15. Mishra Gularaja Sharma, Ayurveda Prakasha by UpodhyayaMadhava, Carith. Arthvidhyothi and Arthaprakashiniskrit and Hindi Commentary), 1st ed Varanasi, Chaukambaorientalia; 2008 sloka 3/287-289

16. Ayurvedic pharmacopoeia ofIndia Part I, vol. 2, 1st ed., Delhi The controlleof publications 2001, Pg.5,26,47

17. Tripathiindradev.RasaratnasamuchayaofVag bhata. $4^{\text {th }}$ edition.Varanasi:Chowkhambha

Sanskrit series office office;2006.5 . p60-62.

18. KrishnaGopalSatputeAsok.Rasendrasarasan graha. $1^{\text {st }}$ edition.Varanasi:ChowkhambhaKri shnadas Academy;1994.1.p104

19. Chaudhary A and Prakash. B, Scientific Validated approach for application of MadhuraBhasmaA Review, Electronic journal of Pharmacology and Therapy Vol. 3. (2010), Pg. 2

20. Sargadhara, Adamalla, Kasirama, Pandita ParasuramaSastry.Sargadharasamhitha by Sargadharacharya,Varanasi:ChowkambhaKr ishnadas Academy; 2013. 11. p256

21. Agnivesa, Charakasamhita, Chaukambhaorientalia, Varanasi, 2008, suthrasthanam, chapter 28 , verses 10

22. Prabhakar G Rao, Chakradatta of Acharya ChakrapaniDatta, $\quad 1^{\text {st }}$ ed. Varanasi: ChaukambhaOrientalia;2014.8.p121

23. Tripathiindradev. Rasaratnasamuchaya of Vaghbhata. $4^{\text {th }}$ ed.Varanasi:choukambha

Sanskrit series office;2006.5.p60-62

24. KrishnaGopalSatputeAsok.Rasendrasarasan graha. $1^{\text {st }}$ edition.Varanasi:ChowkhambhaKri shnadas Academy;1994.1.p108

25. Madhava .Mishra G .Ayurveda Prakasa of Acharya Sri Madhava .Varanasi: Choukamba VidyaBhawan ;2007. 3.p388390

26. Sharma. SRasatarangini, Hindi Commentary, ShastriKashinath, Motilal Banarasi das, Delhi.517 (2000).

27. KrishnaGopalSatputeAsok.Rasendrasarasan graha. $1^{\text {st }}$ edition.Varanasi:chowkhambhaKris hnadas Academy;1994.1. p107 
28. Sargadhara, Adamalla, Kasirama, PanditaParasuramaSastry.Sargadharasamhit ha by Sarngadharacharya, Varanasi: ChowkambhaKrishnadas Academy; 2013. 11. p250

29. Lochan Kanjiv,BhaishajyaRatnavali of GovindaDasji Bhishagratna, Reprint. Vol.2, Varanasi.Chaukambha Sanskrit sansthan, 2008.44 .710

30. TrikamjiYadavji, Rasamritha, (Text book with English translation byDamodar Joshi and G. Prabhakar Rao). 1st ed., Varanasi, U.P Chowkambha Sanskrit Bhavan, 1998.3/150.
31. Sarangadhara, Adamalla, Kasirama, PanditaParasuramaSastry.Sargadharasamhit ha by Sargadharacharya, Varanasi: ChowkambhaKrishnadas Academy; 2013. 11. $\mathrm{p} 256$

32. SidhiNandhanaMisra,Rasendrachintamani of AcharyaDundukanath: Sidhiprada commentary. Varanasi: Chaukamba Orientalia; 2011. p128.

How to cite this article: Uthamsha VP, Sreeni TV. An analytical review on mandura bhasma in classics. Int J Health Sci Res. 2021; 11(11): 102-107. DOI: https://doi.org/10.52403/ijhsr. 20211111

$* * * * * *$ 